\title{
Teaching Effectiveness in Private Higher Education Institutions in Botswana: Analysis of Students' Perceptions
}

\author{
Som Pal Baliyan ${ }^{1} \&$ Fazlur Rehman Moorad ${ }^{1}$ \\ ${ }^{1}$ Department of Educational Foundations, Faculty of Education, University of Botswana, Gaborone, Botswana \\ Correspondence: Som Pal Baliyan, Department of Educational Foundations, Faculty of Education, University of \\ Botswana, Gaborone, Botswana
}

Received: May 17, 2018

Accepted: June 4, 2018

Online Published: June 10, 2018

doi:10.5430/ijhe.v7n3p143

URL: https://doi.org/10.5430/ijhe.v7n3p143

\begin{abstract}
This quantitative study analyzed the perceptions of students on teaching effectiveness in private higher education institutions in Botswana. An exploratory and descriptive survey research design was adopted in this study. A valid and reliable questionnaire was used to collect data through a survey of 560 stratified randomly sampled students in private higher education institutions in Botswana. A One sample t-test and an Independent t-test were used for data analysis. A significant high level of teaching effectiveness was determined. Several items measuring teaching effectiveness contributed significantly negative to teaching effectiveness and therefore, it was recommended that lecturers should use strategies to improve on those areas of teaching to enhance their teaching. No difference in teaching effectiveness was determined with respect to age, gender and nationality of the students. However, there was a significant difference in the students' perceptions on teaching effectiveness between the university and the non- university institutions and, lecturers were found to be more effective in their teaching at the universities as compared to the lecturers in the non -university institutions. Therefore, a further study exploring the factors contributing to such differences is recommended to improve the quality of teaching in the non- university type of private higher education institutions in Botswana.
\end{abstract}

Keywords: Botswana, effective teaching, private higher education, quality of teaching, students' perceptions, university education

\section{Introduction}

Education is one of the greatest tools which influences the socio-economic growth and development of a country. Education enables the citizens to facilitate their duties and responsibilities to their families, society and the country. Thus, higher education has become more of a necessity in a current increasingly competitive knowledge driven global economy (Zuekle, 2008). Higher education is provided by the public and private institutions all over the world. The rise of an information-based economy, changes in demographics, an increase in public scrutiny, the advent of new technologies, the convergence of knowledge-based organizations, and a decline in public trust in government are the factors spurring the spread of privatization in higher education all over the world (Levine, 2018). As private higher education systems grow and diversify, society is increasingly concerned about the quality of education. During the last decade, the quality of teaching and learning in higher education has become a debatable issue in many countries (Chen \& Hoshower, 2003; Slate et al., 2011). The imperative for countries to improve job-related skills calls for quality teaching in the educational institutions particularly, private higher education institutions. Consequently, policymakers have undertaken various reforms to improve the quality of education, ranging from new curricula, establishing quality assurance units, recruiting qualified and experienced staff and continuous professional development of staff. There is a need however for measures to improve the quality of education especially human resources involved in teaching and learning. The consensus among education policymakers, practitioners, and the general public today is that improving teacher quality is one of the most direct and promising strategies for improving the quality of education and thus, learning outcomes (Hammond, 2010). The quality of teaching is one of the important components of the quality of education and can only be improved through enhancing teaching effectiveness for which the evaluation of the teaching quality is required to identify the areas for improvement.

The quality of education has been a concern for decades. Gradually it is becoming more specialized and commercialized throughout the world (Akareem \& Hossain, 2012). Educational debates like the Bologna Process, direct state regulations or incentives, competition among private and public owned institutions have been held, to put 
the quality of teaching on their agenda. The survival of private education institutions largely depends on the income derived from tuition fees from students (Dezhbakhsh and Karikari, 2010). It is also crucial to understand that private education institutions are to serve their customers namely students. Therefore, what students perceive about the quality of education should be understood not only to improve the quality of teaching and learning, but also to increase enrolment and the reputation of the education institutions. The aim and objectives of education and institutions change from time to time depending on the changing needs of the society. The laypersons and professionals believe that the quality of education can be achieved through the efforts of well qualified, competent and effective teachers. Thus, the effectiveness of an educational system particularly, teaching and learning is largely determined by the quality of teachers. Policymakers in the current educational system are at a crucial intersection in which they need to understand to what extent the teachers are effective as it affects student success in the classroom (Sabol, 2013). Therefore, it is crucial for the institutions to understand how students perceive the quality of teaching they are provided so that their expectations can be fulfilled effectively.

Although the evaluation of teaching effectiveness provides the effective and professional ideas to improve their teaching practices (Balam \& Shannon, 2010), it is a highly complex process as it is both subjective and multidimensional. Being the customers of education, students are increasingly becoming the drivers for quality of teaching and are involved in the evaluation processes (Benton and Cahin, 2014). Considering students as the first hand consumers of education, in some countries students are authorized to play an active role in the running and improving of education in their institutions. Therefore, there is a current international trend of increasing the awareness of quality of teaching and, that students are invited to serve on governing bodies of institutions where they are able to put their personal stand point on issues in education particularly those related to teaching and learning (Allan, Clarke and Jopling, 2009; Berk, 2009) and also through surveys on assessment and feedback (Berk, 2012). Although the teaching and learning are important aspects of effective teaching,, they are not the only considerations to be taken into account. The perceptions depend and differ from person to person and obviously, the responses may differ from student to student as the perceptions are based on their personal experiences about teaching.

\subsection{Problem Statement}

Private higher education in Botswana has grown significantly in recent years in terms of the number of institutions, number of students enrolled and, diversity of courses being offered. These institutions have increased remarkably, resulting in the education sector becoming more competitive and yet, many of these cannot ensure the desired quality of education. Researchers' and experts' opinion seems to indicate that the quality of education of many of these institutions is below par; many of them depend on part-time and, inexperienced faculty. Considering the growth and diversification of private higher education institutions and the job market, society and stakeholders are increasingly concerned about the quality of education they offer. Consequently, institutions are expected to provide good quality teaching and therefore, producing good quality learning. As a result, the teaching and its assessments done in these educational institutions are considered important. However, there is no evidence of the quality of teaching in the fast growing private higher education system in the country. So far, no study has been conducted on assessing the current status of quality of teaching in the private higher education institutions in Botswana. Therefore, there is a need to assess the quality of teaching in these institutions. Such assessment may assist stakeholders and policy makers in enhancing the quality of teaching in the country particularly, in private higher education institutions.

\subsection{Aim and Objectives}

The aim of this quantitative study was to assess the quality of teaching (teaching effectiveness) in the private higher education institutions in Botswana. The specific objectives of the study were:

i) To determine the level of teaching effectiveness as perceived by students in private higher education institutions.

ii) To determine the gender difference in teaching effectiveness as perceived by students in private higher education institutions.

iii) To determine the age difference in teaching effectiveness as perceived by students in private higher education institutions.

iv) To determine the nationality difference in teaching effectiveness as perceived by students in private higher education institutions.

v) To determine the difference in teaching effectiveness in university and non- university type of private higher education institutions. 


\section{Review of Literature}

\subsection{Meaning of Teaching Effectiveness}

The word teacher effectiveness is composed of two words; teacher and effectiveness. A teacher is a person who teaches i.e. imparts knowledge and skills to the learner. Effectiveness is the quality of being successful in producing an intended result (Collin's English Dictionary) i.e., effective in imparting knowledge. Thus, the term teacher effectiveness refers to the measure of success of a teacher in carrying out the task of teaching which includes effective methods of instruction, classroom management and organization, assessment and feedback among others.

Teaching effectiveness is a concept that has different meaning to different people. Effective teaching refers to all the behaviours of an instructor that helps students learn (Cashin, 1989). Effective teaching is to provide maximum opportunities for all students to learn (Westwood, 1998). Effective teaching is that the students achieve the learning 'intended by the teacher' (Kyriacou, (2009, p.7); but this does not take into account the fact that learning is a two-way process (Biggs, 2003; Kember and MacNaughton, 2007). The interactions between teachers and students is a two way process whereby teacher teach and students learn but at the same time teachers get feedback on the learning through various assessments.

It is clear that teaching effectiveness is referred to various concepts namely: teacher effectiveness, instructional effectiveness and quality of teaching. This study adopted teaching effectiveness as the quality of teaching and has been used interchangeably throughout this manuscript. Teaching is a process in which a teacher engages physically and/or intellectually with the students, in order to develop in students an interest in learning. Quality is an individual's, subjective perception of satisfaction with a product and/or service. In this study, quality refers to the students perceptions on the level of their satisfaction on the teaching process. Perception is the personal opinion on the basis of which a student chooses, organizes and interprets information to have a clear picture of the teaching process.

\subsection{Students' Perceptions as Measurement of Teaching Effectiveness}

There are various strategies to measure teaching effectiveness which include student ratings, peer ratings, selfevaluation, videos, student interviews, alumni ratings, employer ratings, administrator ratings, teaching scholarship, teaching awards, learning outcome measures and teaching portfolio (Berk, 2012). Teaching effectiveness has mostly been measured through a perception based student questionnaire specifically designed to measure observed teaching styles or behaviors of the teacher (Wright \& O'Neil, 1992; Cashin, 1995). "Any use of student evaluations [of teaching effectiveness] must be based on the assumption that students are willing and able to provide valid judgments about the teaching they have received" (Kwan, 2000, p. 20).

Based on the perceptions of the students, numerous instruments have been developed worldwide for evaluating teaching effectiveness in higher education such as the "Students' Evaluation of Teaching Effectiveness Rating Scale" (Toland, \& De Ayala, 2005), the "Teaching Proficiency Item Pool" (Barnes et al., 2008) and the questionnaire to evaluate teaching (Mortelmans, \& Spooren, 2009). However, all these data collection instruments differ in their components or items for evaluation of teaching quality; mostly they share similar dimensions identified by different researchers (Dodeen, 2013; Toland and Alyala, 2005; Gursoy and Umbreit, 2005; and Catano \& Harvey, 2011).

Barnett (2011), Fenstermacher and Richardson (2005) asserted that students' perception of effective teaching is necessary for improving the effectiveness of teaching and therefore, their learning. Allan and Clarke (2007), Allan, Clarke and Jopling (2009) and Kember and MacNaughton (2007) suggested that there is a link between effective teachers and their personal attributes. The availability of the professor, clarity of their presentation, systematic approach in teaching, the information given to the students, encouraging active participation in class and, considering and responding to the students' questions are indicators of effective teaching and learning (Kuzmanovic, Savic, Gusavac, Makajic-Nikolic, \& Panic, 2013).

Similarly, Rama (2011) determined that the most effective professors are the ones that know their students' needs and try to increase their motivation, use different teaching strategies, possess good communication skills, and encourage the students to be optimistic about their abilities. Conversely, effective teachers are those who improve student learning by enhancing several factors including student motivation, persistence, creativity, knowledge applicability, and global competency (Byrd \& Rasberry, 2011). Thus, Allan, Clarke and Jopling (2009), and Barnett and Di Napoli (2008) suggested that students decide the effectiveness of teaching of their teachers based on their understanding of the teaching styles.

Although student perception surveys have shown to be effective in evaluating teacher effectiveness, their use in the high-stakes realm of performance reviews is not widespread (Khong, 2014; Onwuegbuzie, Daniels, \& Collins, 2009). 
In studies tracking student evaluations of faculty, researchers noted an increase from $29 \%$ to $86 \%$ in a twenty year period (Emery, Kramer, \&Tian, 2003). Although there are still certain controversies that most of the teaching evaluation instruments were not validated (Spooren, Brockx and Mortelmans, 2013), there are advantages of student perception surveys to evaluate faculty teaching effectiveness. Perhaps the most important advantage of using student surveys is their ability to provide applicable feedback to teachers which teachers can use survey results to identify strengths and weaknesses and make changes to their teaching methods. The datasets of students' perceptions can be used in the process of promotion and tenure as well as to guide faculty members in improving their performance (Sarkis and Inshik, 2010). Students surveys provide direct feedback to the faculty and minimize bias compared to one-time outside reviews. These tools are low cost with a rapid turnaround, they have been an ease of scale revision and, they are efficient and easy to implement (Turhan, Yaris, and Nural, 2005). Surveys are time-efficient, cost-efficient, can be collected anonymously and, have the ability to track changes over time and, require minimal training (Goe, et al., 2008).

Feedback from students is an integral part of the evaluation of the teaching process as it lets the concerned parties know the progress of a class, areas of strength and weaknesses (Lawall, 1998; Annan et. al., 2013; Marsh, 2007). Feedback from students is an essential requirement of reflective teaching, allowing teachers to refine their practice and to continue developing as professionals. This doesn't just apply to instructors whose performance is shaky or weak, in fact even the best teachers can benefit from student feedback. Therefore, getting information from students can be very helpful in improving teaching and obviously, the quality of education. Many methods can be used to obtain feedback (Berk, 2013). Student Evaluation of Teaching (SET) has been extensively used (Algozzine et al., 2004; Clayson, 2009). Whilst, no general consensus has been reached about the validity of the SET, it seems there is some criticism against relying entirely on student feedback to evaluate teaching methods and effectiveness (Clayson, 2009; Kogan et al., 2010 \& Nilson, 2016). Despite this, student ratings are used as one of the most influential measures of teaching effectiveness (Harvey, 2003). The literature suggests that satisfaction surveys predominate (Frick et al., 2009; Kember \& Leung, 2009) in teaching effectiveness with the assumption that students provide feedback on the satisfaction of survey honesty.

\section{Methodology}

\subsection{Research Design}

This quantitative study adopted an exploratory and descriptive survey research design. A quantitative study involves data collection from a large population. It is then used to generalize the results for the entire target population (Hollensen, 2003). Cooper and Schindler (2006) indicated that the broad area of survey research encompasses any measurement procedures that involve asking questions or perceptions from respondents. Surveys are divided into four major types: personal interviews, telephone surveys, mail surveys and self-administered surveys (Gerber-Nel, $\mathrm{Nel}$ and Kotze, 2005). Data was collect through a survey whereby questionnaires were self-administered by the researcher. A survey was found appropriate for data collection as it is useful for gathering factual information on preferences, beliefs and experiences from a wide range of participants (Cohen et al., 2007; Fraenkel et al., 2012).

\subsection{Sampling and Sample}

The population for this study consisted of the final year students enrolled in the university and non- university type of private higher education institutions in Botswana. Final year students were considered for this study as an effort to capture their perceptions on the quality of teaching as they had gone through the teaching and learning process in these institutions for some years. Two universities and two non-university private higher education institutions in Botswana were randomly sampled. Further, a stratified random sampling method was used to select an equal number of 140 students from each of the four sampled institutions. The gender of students and type of institutions were considered as the two strata for sampling. Thus, 70 male and 70 female students from each of the four selected university and non-university institutions were selected. Thus, a total sample of 560 students $(n=560)$ were selected for this study. A stratified random sampling procedure reduces the sampling error. In addition, stratification can ensure that each sub-division of the population is adequately represented in the sample.

\subsection{Instrumentation}

A valid and reliable questionnaire was constructed for data collection. The questionnaire was developed based on the literature review. The questionnaire was divided into two sections. The first section of the questionnaire consisted of items on the demographic information of the respondents. The second part contained 40 items to measure students perceptions on the teaching effectiveness on a four-point Likerts' scale ranging from 1=Strongly Disagree, 2=Disagree, 3=Agree, 4=Strongly Agree. However, the majority of the items in the second section of the 
questionnaire were extracted from the instrument used by Al-Hinai, (2011). The items were modified for simplicity and, to suit to the purpose of this study. The validity of the questionnaire was accomplished by an expert review panel composed of three faculty experts in educational management and educational research. The reliability of the instrument was ensured by calculating the Cronbach Alfa Coefficient. The reliability coefficient of the 40 items measuring teaching effectiveness on a 4-point Likerts' scale was calculated at .829 indicating that the questionnaire was reliable (Creswell \& Creswell, 2017; Field, 2009).

\subsection{Data Collection and Data Analysis}

A valid and reliable questionnaire was used to collect data through a survey of the sampled students. On an agreed date and time, the researcher visited the selected institutions and distributed the questionnaires to the sampled students in their respective classes. The students were asked to complete the questionnaires before leaving the class and, students were not allowed to take the questionnaire away. Therefore, all the distributed questionnaires were collected immediately after completion. The Statistical Package for Social Sciences (SPSS) software ver. 23 was used for data analysis whereby a One sample t-test and Independent t-tests were used. A One sample t-test was employed to determine the level of teaching effectiveness while an Independent t-test was employed to determine the gender, age, nationality differences in the students' perceptions on teaching effectiveness. Before performing any statistical analysis, the missing values for the variables were substituted with its mean. Mean substitution is a valid approach for dealing with missing values (Sen, et al., 2018; Cheema, 2014; Graham, et al., 2003).

\section{Results and Discussion}

\subsection{Level of Teaching Effectiveness as Perceived by Students}

A One sample t-test was employed to determine the level of teaching effectiveness as perceived by the students in the private higher education institutions in Botswana and the results are presented in Table 1. The overall level of teaching effectiveness was determined higher by $13.49 \%(\overline{\mathrm{x}} \mathrm{D}=13.49, \mathrm{t}=26.99, \mathrm{p}=.01)$ than the average level of teaching effectiveness $(\overline{\mathrm{x}}=100.00)$. All the forty items measuring the level of teaching effectiveness were found statistically significant at the .01 level. The top three items contributing positively to teaching effectiveness were determined. These items with their mean difference $(\overline{\mathrm{x}} \mathrm{D})$ and significance are showing strong enthusiasm for the subject $(\overline{\mathrm{x}} \mathrm{D}=1.213, \mathrm{t}=52.23, \mathrm{p}=.01)$, effective preparation and presentation of contents $(\overline{\mathrm{x}}=1.164, \mathrm{t}=42.50, \mathrm{p}$ $=.01)$ and, enhancing presentation with the use of humour $(\overline{\mathrm{x}} \mathrm{D}=1.143, \mathrm{t}=37.64, \mathrm{p}=.01)$.

On the other hand Table 1 indicated that 11 items contributed significantly negative to the teaching effectiveness. These items with their mean difference and significance included up to date knowledge of the $\operatorname{subject}(\overline{\mathrm{x}} \mathrm{D}=-.898$, $\mathrm{t}=-43.38, \mathrm{p}=.01)$, adheres to stipulated course objectives $(\overline{\mathrm{x}} \mathrm{D}=-.816, \mathrm{t}=-23.03, \mathrm{p}=.01)$, encourages students to participate in classroom activities $(\overline{\mathrm{x}} \mathrm{D}=-.707, \mathrm{t}=-19.17, \mathrm{p}=.01)$, ensuring that students responses during classroom discussion are meaningful $(\overline{\mathrm{x}} \mathrm{D}=-.686, \mathrm{t}=-19.17, \mathrm{p}=.01)$, giving content focused homework for effective learning $(\overline{\mathrm{x}} \mathrm{D}=-.375, \mathrm{t}=-13.50, \mathrm{p}=.01)$, provides background for concepts presented $(\overline{\mathrm{x}} \mathrm{D}=-.355, \mathrm{t}=$ $-21.28, \mathrm{p}=.01)$, welcomes students seeking help $(\overline{\mathrm{x}} \mathrm{D}=-.345, \mathrm{t}=-13.32, \mathrm{p}=.01)$, stimulates interest of students in the subject $(\overline{\mathrm{x}} \mathrm{D}=-.339, \mathrm{t}=-19.42, \mathrm{p}=.01)$, making the course intellectually challenging and stimulating $(\overline{\mathrm{x}} \mathrm{D}=$ $-.299, \mathrm{t}=-16.05, \mathrm{p}=.01)$, having a genuine academic interest in individual students $(\overline{\mathrm{x}} \mathrm{D}=-.298, \mathrm{t}=-11.73, \mathrm{p}=.01)$ and, giving valuable feedback on assessments/graded material $(\overline{\mathrm{x}} \mathrm{D}=-.298, \mathrm{t}=-15.21, \mathrm{p}=.01)$. These findings reflected that the teachers are of poor quality in these areas of teaching and therefore, need to improve on all these areas of their teaching.There is a huge body of literature suggesting that the teaching effectiveness can be improved if the lecturers improve in the areas of teaching in which they are still not good enough and, contribute negatively to their teaching effectiveness. 
Table 1. One Sample t-test determining the Teaching Effectiveness as Perceived by students in Private Higher Education Institutions ( $\mathrm{df}=559)$

\begin{tabular}{|c|c|c|c|c|c|}
\hline Items & $\bar{x}$ & $S D$ & $S E(\bar{x})$ & $\bar{x} D$ & t-value \\
\hline 1. Good command of the subject contents & 2.87 & 1.008 & .043 & $.368^{* *}$ & 8.63 \\
\hline 2. Enthusiasm for the subject & 3.71 & .549 & .023 & $1.213^{* *}$ & 52.23 \\
\hline 3. Creates a challenging and stimulating content delivery & 2.20 & .437 & .018 & $-.299^{* *}$ & -16.05 \\
\hline 4. Stimulates interest of students in the subject & 2.16 & .413 & .017 & $-.339^{* *}$ & -19.42 \\
\hline 5. Dedication to teaching & 2.92 & .870 & .037 & $.416^{* * *}$ & 11.31 \\
\hline 6. Well prepared and delivered course material & 3.66 & .648 & .027 & $1.164^{* *}$ & 42.50 \\
\hline 7. Welcomes students seeking help & 2.16 & 612 & .026 & $-.345^{* *}$ & -13.32 \\
\hline 8. Relevant academic qualifications to teach the subject & 3.46 & .779 & .033 & $.959^{* *}$ & 29.13 \\
\hline 9. Giving content focused home work for effective learning & 2.13 & 657 & .028 & $-.375^{* *}$ & -13.50 \\
\hline 10. Presenting other views when appropriate & 2.59 & .663 & .028 & $.091^{* * *}$ & 3.25 \\
\hline 11. Effective presentation to create students' interest & 2.67 & .983 & .042 & $.170^{* *}$ & 4.08 \\
\hline 12. Effective use of instructional media and teaching aids & 3.27 & .841 & .036 & $.766^{* *}$ & 21.55 \\
\hline 13. Adhere to stipulated course objectives & 1.68 & .839 & .035 & $-.816^{* *}$ & -23.03 \\
\hline 14. Dynamic and energetic in teaching & 3.12 & .984 & .042 & $.621^{* * *}$ & 14.93 \\
\hline 15. Encourages students to participate in classroom activities & 1.79 & .873 & .037 & $-.707^{* *}$ & -19.17 \\
\hline 16. Interest and care for individual students & 2.20 & 601 & .025 & $-.298^{* * *}$ & -11.73 \\
\hline 17. Provides background for concepts presented & 2.14 & .395 & .017 & $-.355^{* *}$ & -21.28 \\
\hline 18. Equipped with adequate teacher training in teaching the subject & 3.21 & .945 & .040 & $.712^{* *}$ & 17.83 \\
\hline 19. Up to date knowledge of the subject & 1.60 & .490 & .021 & $-.898^{* *}$ & -43.38 \\
\hline 20. Encourages students to share their ideas & 3.33 & .860 & .036 & $.827^{* * *}$ & 22.75 \\
\hline 21. Demonstrating good skills in classroom management & 2.98 & 1.095 & .046 & $.482^{* *}$ & 10.42 \\
\hline 22. Showing respect for all students & 3.07 & 1.127 & .098 & $.568^{* *}$ & 11.92 \\
\hline 23. Provides advice and support to students & 3.37 & .968 & .041 & $.866^{* *}$ & 21.16 \\
\hline 24. Sensitive to the culture of the organization and society & 3.58 & .706 & .030 & $1.077^{* *}$ & 36.08 \\
\hline 25. Effective application of student-centered approaches in teaching & 2.81 & .511 & .022 & $.305^{* *}$ & 14.15 \\
\hline 26. Encouraging students to ask questions in class & 3.60 & .760 & .032 & $1.096^{* *}$ & 34.14 \\
\hline 27. Application of diversity and appropriate teaching methods & 3.21 & .953 & .040 & $.712^{* *}$ & 17.69 \\
\hline 28. Inculcates a sense of humour during presentation & 3.64 & .718 & .030 & $1.143^{* *}$ & 37.64 \\
\hline 29. Giving valuable feedback on assessments/graded material & 2.20 & .464 & .020 & $-.298^{* *}$ & -15.21 \\
\hline 30. Clear and effective explanations & 3.61 & .722 & .031 & $1.105^{* *}$ & 36.20 \\
\hline 31. Assigning work on the content taught & 3.63 & 690 & .029 & $1.134^{* *}$ & 38.90 \\
\hline 32. Encourages students to express their own ideas & 3.06 & .927 & .039 & $.557^{* *}$ & 14.22 \\
\hline 33. Adequate and relevant experience in teaching the subject & 3.02 & 1.069 & .045 & $.516^{* * *}$ & 11.42 \\
\hline 34. Being friendly toward individual students & 2.66 & .645 & .027 & $.164^{* *}$ & 6.02 \\
\hline 35. Giving timely feedback on assessments/graded material & 3.03 & .997 & .042 & $.532^{* *}$ & 12.63 \\
\hline 36. Provides enough time to students for taking notes & 3.09 & .983 & .042 & $.591^{* *}$ & 14.22 \\
\hline 37. Implements an adequate number of assessments & 2.93 & 1.012 & .043 & $.434^{* *}$ & 10.14 \\
\hline 38. Use of appropriate assessment methods & 2.62 & 1.073 & .045 & $.123^{* *}$ & 2.71 \\
\hline 39. Accommodates students of different learning abilities & 2.69 & .999 & .042 & $.189^{* * *}$ & 4.48 \\
\hline 40. Promotes meaningful discussion in class & 1.81 & .821 & .035 & $-.686^{* *}$ & -19.76 \\
\hline Overall teaching effectiveness & 113.49 & 11.823 & .491 & $13.494^{* *}$ & 26.99 \\
\hline
\end{tabular}

** Mean differences ( $\overline{\mathrm{x}} \mathrm{D})$ are significant at .01 levels.

Akareem \& Hossain (2012) found that faculty characteristics influence the quality of education to a higher extent. Akter (2017) reported that inexperienced faculty was among the top factors affecting the equality of education. Student motivations, interest in their studies, feedback exchange and activeness can guarantee a higher study quality (Lamanauskas \& Makarskaite, 2016). University instructors should have skill, be knowledgeable, informed, and prepared in order to create optimum learning experiences (Flinders, 2013). Solis and Turner (2017) determined that managing course expectations can create positive student-instructor interactions in classrooms which in turn enhance student learning and engagement. Student involvement and effort are key factors to success in teaching and learning 
(Webber, Krylow, \& Zhang, 2013). Effective instructors commonly pride themselves on having positive student interactions in and out of the classroom, provide prompt feedback, and encourage teamwork amongst students (Hammer, Piascik, Medina, Pittenger, Rose, Creekmore, Soltis, Bouldin, Schwarz, \& Scott, 2010). Instructors who take their time to know their students create a more productive and proactive classroom experience and stimulate student motivation and classroom discussion (Weimer, 2010).

Faculty who encourage students to come to office hours, and demonstrate a genuine personal and academic interest in students report stronger student outcomes (Cox, McIntosh, Terenzini, Reason, \&Louvsky-Quaye, 2010). Creating a stimulating and engaging classroom environment is pivotal to student success. Williams et al., (2013) found that students who experience positive emotions and are stimulated in the classroom also experience higher levels of motivation, and demonstrate behaviours that lead to academic success including studying, attendance, enhanced participation, and increased understanding of course materials. Involvement and engagement are the main components of effective teaching and learning. Impactful teachers also obtain and implement constructive feedback to encourage active learning (Hammer et al., 2010). Macsuga-Gage et al., (2012) found that the most effective teachers deliver concrete, explicit, and engaging instruction, assign students activities that promote understanding of skills and knowledge, provide positive feedback on students' academic performance and, build strong relationships with their students. Most recently Paolini, (2015) concluded that the most impactful instructors utilize specific interventions including creating stimulating curricula, interacting with students, being available and approachable, using differential instruction and addressing relevant material. In order to achieve all this, the instructors have to be prepared and well-versed in their subject matter, design courses that reflect standards, and clearly communicate course content and expectations (Paolini, 2015).

\subsection{Gender Difference in Teaching Effectiveness as Perceived by Students}

An Independent t-test was employed to determine the gender difference in teaching effectiveness as perceived by the students in private higher education institutions in Botswana and the results are presented in Table 2.

Table 2 indicates that no gender significant difference was determined in the students' perceptions on teaching effectiveness. However, female students reflected better teaching effectiveness $(\overline{\mathrm{x}}=12.04)$ as compared to the male students $(\overline{\mathrm{x}}=11.65)$. These findings indicated that both male and female students perceived the quality of teaching almost at the same level. These findings are contradictory with the findings of Alhjia (2017) and Akreem \& Hossain, (2016) who found that a gender difference exists in students' perceptions about teaching in higher education. According to Ramachandran (2010) there are very few studies based on gender issues particularly in higher education. Clearly more studies are needed in this important area.

Table 2. Independent T-Test of the Gender Difference in the Students' Perceptions toward Teaching Effectiveness $(\mathrm{df}=558)$

\begin{tabular}{|c|c|c|c|c|c|c|c|}
\hline \multirow[t]{2}{*}{ Gender } & \multirow[t]{2}{*}{$n$} & \multirow[t]{2}{*}{$\overline{\boldsymbol{x}}$} & \multirow[t]{2}{*}{$S D$} & \multicolumn{2}{|l|}{ difference } & \multirow[t]{2}{*}{ t-value } & \multirow[t]{2}{*}{ Sig. } \\
\hline & & & & $\bar{x}$ & $S E D$ & & \\
\hline Male & 305 & 113.18 & 11.65 & & & & \\
\hline Female & 255 & 113.85 & 12.04 & -.67 & 1.00 & -.676 & .499 \\
\hline
\end{tabular}

\subsection{Age Difference in Teaching Effectiveness as Perceived by Students}

An Independent t-test was employed to determine the age difference in teaching effectiveness as perceived by the students in private higher education institutions in Botswana and the results are presented in Table 3.

Table 3 indicated no significant age difference was determined in the students' perceptions towards teaching effectiveness. However, students with age of 18 and below reflected better teaching effectiveness $(\bar{x}=113.60)$ as compared to the students with age of 19 years and above $(\overline{\mathrm{x}}=113.46)$. These findings reflected that both the age group of students perceived the quality of teaching at the same level. This finding is contrary to the finding of 
Akreem \& Hossain, (2016) who found that age has a significant difference in the students' perception about quality of teaching in higher education.

Table 3. Independent T-Test determining the Age Difference in the Students' Perceptions toward Teaching Effectiveness in Private Higher Education Institutions ( $\mathrm{df}=558$ )

\begin{tabular}{|c|c|c|c|c|c|c|c|}
\hline \multirow[t]{2}{*}{ Age } & \multirow[t]{2}{*}{$n$} & \multirow[t]{2}{*}{$\bar{x}$} & \multirow[t]{2}{*}{$S D$} & \multicolumn{2}{|c|}{ difference } & \multirow[t]{2}{*}{ t-value } & \multirow[t]{2}{*}{ Sig. } \\
\hline & & & & $\bar{x}$ & $S E D$ & & \\
\hline 19 years and below & 106 & 113.60 & 10.59 & & & & \\
\hline 20 years and above & 454 & 113.46 & 12.10 & .14 & 1.27 & .111 & .912 \\
\hline
\end{tabular}

\subsection{Nationality Difference in Teaching Effectiveness as Perceived by Students}

An Independent t-test was employed to determine the nationality difference in teaching effectiveness as perceived by the students in private higher education institutions in Botswana and the results are presented in Table 4.

Table 4 indicates that no significant difference in students' nationality was determined in the students' perceptions towards teaching effectiveness. However, students from Botswana reflected better teaching effectiveness $(\overline{\mathrm{x}}=$ 113.56) as compared to the students from other nationalities $(\overline{\mathrm{x}}=112.00)$. These findings indicated that the students from Botswana as well as from other countries, perceived the quality of teaching at the same level.

Table 4. Independent T-Test determining the Nationality Difference in the Students' Perceptions toward Teaching Effectiveness in Private Higher Education Institutions ( $\mathrm{df}=558$ )

\begin{tabular}{|c|c|c|c|c|c|c|c|}
\hline \multirow[t]{2}{*}{ Nationality } & \multirow[t]{2}{*}{$n$} & \multirow[t]{2}{*}{$\bar{x}$} & \multirow[t]{2}{*}{$S D$} & \multicolumn{2}{|l|}{ difference } & \multirow[t]{2}{*}{ t-value } & \multirow[t]{2}{*}{ Sig. } \\
\hline & & & & $\bar{x}$ & SED & & \\
\hline Batswana & 534 & 113.56 & 11.77 & & & & \\
\hline Others & 26 & 112.00 & 12.97 & 1.56 & 2.37 & .657 & .511 \\
\hline
\end{tabular}

\subsection{Institutional Difference in Teaching Effectiveness as Perceived by Students}

An Independent t-test was employed to determine the institution type difference in teaching effectiveness as perceived by the students in private higher education institutions in Botswana and the results are presented in Table 5.

Table 5 indicated that a significant difference in the students' perceptions towards teaching effectiveness in the university and non university type of private higher education was determined $(\overline{\mathrm{x}}=-2.89, \mathrm{t}=-2.90, \mathrm{p}=.004)$. Moreover, students studying in the university type institutions perceived better teaching effectiveness $(\overline{\mathrm{x}}=114.93)$ as compared to the students in the non university type institutions $(\overline{\mathrm{x}}=112.04)$. It clearly reflects that teachers in the university type of private higher institutions are of higher quality than the teachers in the non university type of institutions.This difference can be attributed by several factors including the use of technology for teaching and learning (Price \& Kirkwood, 2014; Englund, et al., 2017); the availability of physical resources such as a library and laboratory (Gibbs \& Jenkins, 2014, teaching large classes(Gibbs \& Jenkins, 2014, Maring \& Sing, 2014), poor student engagement (Shernoff, et al., 2014), academic advising, communication skills and qualifications of academic staff (Noaman, et al., 2017). 
Table 5. Independent T-Test determining the Institution Type Difference in the Students Perceptions toward Teaching Effectiveness in Private Higher Education Institutions ( $\mathrm{df}=558)$

\begin{tabular}{|c|c|c|c|c|c|c|c|}
\hline \multirow[t]{2}{*}{ Institution type } & \multirow[t]{2}{*}{$n$} & \multirow[t]{2}{*}{$\bar{x}$} & \multirow[t]{2}{*}{$S D$} & \multicolumn{2}{|l|}{ difference } & \multirow[t]{2}{*}{ t-value } & \multirow[t]{2}{*}{ Sig. } \\
\hline & & & & $\bar{x}$ & $S E D$ & & \\
\hline Non University & 280 & 112.04 & 12.81 & & & & \\
\hline University & 280 & 114.93 & 10.57 & -2.89 & .99 & -2.90 & $.004 * *$ \\
\hline
\end{tabular}

** Mean differences $(\overline{\mathrm{x}} \mathrm{D})$ are significant at .01 levels.

Further, Richardson, (2005) revealed the relationships between teachers' approaches to teaching; their conceptions of teaching, and their perceptions of the teaching environment vary among the academic staff in different institutions and, influences their teaching. The quality culture among the leaders and teachers are of different ability to influence resource allocation, clarify roles and responsibilities which may have influence on teaching and learning process (Bendermacher, et al., 2017). This difference in the quality of teaching may also be attributed by several other factors including motivation level of teachers, remuneration of the teachers and working environment etc. and therefore, such factors need thorough investigation to narrow down the gap in quality of teaching in the university and non- university private higher education institutions.

\section{Conclusion and Recommendations}

The overall level of teaching effectiveness in the private higher education institutions was found to be higher than the average level of teaching effectiveness. Among the forty items measuring the teaching effectiveness, the top three items which were found to be significantly positive included; showing strong enthusiasm for the subject, well prepared and delivered course materialand, enhancing presentation with the use of humour. On the other hand, several items measuring the teaching effectiveness were found to be significantly negative namely; up to date knowledge of the subject, adhere to stipulated course objectives, encourage students to participate in classroom activities, ensuring that students responses during classroom discussion are meaningful, assigning homework/readings, providing background for concepts presented, welcoming students seeking help, stimulating interest of students in the subject, making the course intellectually challenging and stimulating, having an academic interest in individual students and, giving valuable feedback on assessments/graded material. In order to improve on teaching effectiveness, it is, therefore recommended that the lecturers should improve on the components of teaching which contributed negatively to the teaching effectiveness.

No significant gender and age difference in the perceptions of students' on the teaching effectiveness was determined. Also, no significant difference in the perceptions of students from Botswana and other countries was determined. However, teaching effectiveness was differently perceived by the students studying in the university and non university type of private higher institutions whereby lecturers were found to be more effective in university type institutions compared to the lecturers in the non -university institutions. Therefore, a further study exploring the factors contributing to the differences in teaching effectiveness between the university and the non- university institutions in Botswana is recommended for improving the quality of teaching, According to Ramachandran (2010) whilst universities and other institutions of higher education are strategically placed to undertake multidisciplinary research, unfortunately gender issues have not been given adequate attention. Based on Ramchandrans' findings, UNESCO recommends gender mainstreaming and further recommends studies aimed at identifying gaps through the use of gender analysis and sex disaggregated data. Clearly this is very relevant even in the Botswana context where a dearth of literature in this area exists.

\section{References}

Akareem, H. S., \& Hossain, S. S. (2016). Determinants of education quality: what makes students' perception different?. Open Review of Educational Research, 3(1), 52- 67. https://doi.org/10.1080/23265507.2016.1155167

Akareem, H. S., \& Hossain, S. S. (2012). Perception of education quality in private universities of Bangladesh: a study from students' perspective. Journal of Marketing for Higher Education, 22(1), 11-33. https://doi.org/10.1080/08841241.2012.705792 
Akter, A. (2017). Factors to Improve the Quality of Higher Education in the Non Government Universities in Bangladesh. International Journal of Education, Culture and Society,2(4), 132. http://dx.doi.org/10.11648/j.ijecs.20170204.15

Algozzine, B., Gretes, J., Flowers, C., Howley, L., Beattie, J., Spooner, F., ...\& Bray, M. (2004). Student evaluation of college teaching: A practice in search of principles. College teaching, 52(4), 134-141. https://doi.org/10.3200/CTCH.52.4.134-141

Alhija, F. N. A. (2017). Teaching in higher education: Good teaching through students' lens. Studies in Educational Evaluation, 54, 4-12. https://doi.org/10.1016/j.stueduc.2016.10.006

Al-Hinai, N. A. S. S. E. R. (2011). Effective college teaching and students' ratings of teachers: what students think, what faculty believe, and hat actual ratings show implications for policy and practice in teaching quality assurance and control in higher education in Oman (Doctoral dissertation, durham university).

Annan, S. L., Tratnack, S., Rubenstein, C., Metzler-Sawin, E., \&Hulton, L. (2013). An integrative review of student evaluations of teaching: Implications for evaluation of nursing faculty. Journal of Professional Nursing, 29(5), e10-e24. http://dx.doi.org/10.1016\%2Fj.profnurs.2013.06.004

Balam, E. M., \& Shannon, D. M. (2010). Student ratings of college teaching: A comparison of faculty and their students. Assessment \& Evaluation in Higher Education, 35(2), 209-221. https://doi.org/10.1080/02602930902795901

Barnes, D. C., Engelland, B. T., Matherne, C. F., Martin, W. C., Orgeron, C. P., Ring, J. K., ... \& $\quad$ Williams, $\quad$ Z. (2008). Developing a Psychometrically Sound Measure of Collegiate Teaching Proficiency. College Student Journal, 42(1).

Benton, S. L., \& Cashin W. E. (2012). Student ratings of teaching: A summary of research and literature (IDEA Paper no. 50). Manhattan, KS: The IDEA Center. Retrieved from http://www.theideacenter.org/sites/default/files/idea-paper_50.pdf.

Benton, S. L., \& Cashin, W. E. (2014). Student ratings of instruction in college and university courses.In M. B. Paulsen (Ed.), Higher education: Handbook of theory and research (pp. 279-326). Dordrecht, The Netherlands: Springer. https://doi.org/10.1007/978-94-017-8005-6_7

Berk, R. A. (2009). Using the 360 multisource feedback model to evaluate teaching and professionalism. Medical teacher, 31(12), 1073-1080. https://doi.org/10.3109/01421590802572775

Berk, R. A. (2005). Survey of 12 strategies to measure teaching effectiveness. International journal of teaching and learning in higher education, 17(1), 48-62.http://www.isetl.org/ijtlhe/

Berk, R. A. (2013). Top five flashpoints in the assessment of teaching effectiveness. Medical Teacher, 35(1), 15-26. http://psycnet.apa.org/doi/10.3109/0142159X.2012.732247

Berk, R. A. (2014). Should Student Outcomes Be Used to Evaluate Teaching?. The Journal of Faculty Development, 28(2), 87.

Bendermacher, G. W. G., Oude Egbrink, M. G. A., Wolfhagen, I. H. A. P., \& Dolmans, D. H. J. M. (2017). Unravelling quality culture in higher education: a realist review. Higher Education, 73(1), 39-60. https://doi.org/10.1007/s10734-015-9979-2

Cashin, W.E. (1989). Defining and evaluating college teaching. IDEA Paper No. 21. Manhattan, KS: Centre for faculty Evaluation and Development, Division of Continuing Education, Kansas State University. Retrieved from http: //www.idea.ksu.edu.

Cashin, W.E. (1995). Student ratings of teaching: The research revisited. IDEA Paper No. 32. Manhattan, KS: Centre for faculty Evaluation and Development, Division of Continuing Education, Kansas State University. Retrieved from http: // www.idea.ksu.edu.

Cohen, L. Manion, L. \& Morris, K. (2007). Research methods in education $\left(6^{\text {th }}\right.$ ed). London: Routledge Falmer.

Catano, V. M., \& Harvey, S. (2011). Student perception of teaching effectiveness: development and validation of the Evaluation of Teaching Competencies Scale (ETCS). Assessment \&Evaluation in Higher Education, 36(6), 701-717. https://doi.org/10.1080/02602938.2010.484879

Cheema, J. R. (2014). A review of missing data handling methods in education research. Review of Educational Research, 84(4), 487-508. http://www.jstor.org/stable/24434247 
Chen, Y., \& Hoshower, L. B. (2003). Student evaluation of teaching effectiveness: An assessment of student perception and motivation. Assessment \& evaluation in higher education, 28(1), 71-88.

Clayson, D. E. (2009). Student evaluations of teaching: Are they related to what students learn? A meta-analysis and review of the literature. Journal of Marketing Education, 31(1), 16-30. https://doi.org/10.1177/0273475308324086

Cox, B. E., McIntosh, K. L., Terenzini, P. T., Reason, R. D., \& Luovsky Quaye, B. R. (2010). Pedagogical signals of faculty approachability: Factors shaping faculty-student interaction outside the classroom. Research in Higher Education, 5, 767-788. https://doi.org/10.1007/s11162-010-9178-z

Creswell, J. W., \& Creswell, J. D. (2017). Research design: Qualitative, quantitative, and mixed methods approaches. Sage publications.

Dezhbakhsh, H., \& Karikari, J. A. (2010). Enrollment at highly selective private colleges: who is left behind?. Contemporary Economic Policy, 28(1), 94-109. https://doi.org/10.1111/j.1465-7287.2009.00166.x

Dodeen, H. (2013). Validity, reliability, and potential bias of short forms of students' evaluation of teaching: The case of UAE university. Educational Assessment, 18(4), 235-250. https://doi.org/10.1080/10627197.2013.846670

Emery, C. R., Kramer, T. R., \& Tian, R. G. (2003). Return to academic standards: A critique of student evaluations of teaching effectiveness. Quality assurance in Education, 11(1), 37-46. https://doi.org/10.1108/09684880310462074

Englund, C., Olofsson, A. D., \& Price, L. (2017). Teaching with technology in higher education: understanding conceptual change and development in practice. Higher Education Research \& Development, 36(1), 73-87. https://doi.org/10.1080/07294360.2016.1171300

Field, A. (2009). Discovering statistics using SPSS. Sage publications.

Flinders University (2013). Considering evaluation. Retrieved from http://www.flinders.edu.au/teaching/quality/evaluation/considering-evaluation.cfm.

Frick, T. W., Chadha, R., Watson, C., Wang, Y., \& Green, P. (2009). College student perceptions of teaching and learning quality. Educational Technology Research and Development, 57(5), 705-720.

Gibbs, G., \& Jenkins, A. (2014). Teaching large classes in higher education: How to maintain quality with reduced resources. Routledge.

Goe, L., Bell, C., \& Little, O. (2008). Approaches to Evaluating Teacher Effectiveness: A Research Synthesis. National Comprehensive Center for Teacher Quality.

Graham, J. W., Cumsille, P. E., \&Elek - Fisk, E. (2003). Methods for handling missing data. Handbook of psychology. https://doi.org/10.1002/0471264385.wei0204

Gursoy, D., \& Umbreit, W. T. (2005). Exploring students' evaluations of teaching effectiveness: What factors are important?. Journal of Hospitality \& $\quad$ Tourism Research, 29(1), 91-109. https://doi.org/10.1177/1096348004268197

Hammer, D., Piascik, P, Medina, M., Pittenger, A., Rose, R., Creekmore, F., Soltis, R., Bouldin, A., Schwarz, L., \& Steven, S. (2010). Recognition of teaching excellence. American Journal of Pharmaceutical Education, 74, 1-11.

Harvey, L. (2003). Student feedback [1]. Quality in higher education,9(1), 3-20.https://doi.org/10.1080/13538320308164

Kember, D., \& Leung, D. Y. (2009). Development of a questionnaire for assessing students' perceptions of the teaching and learning environment and its use in quality assurance. Learning Environments Research, 12(1), 15-29. https://doi.org/10.1007/s10984-008-9050-7

Khong, T. L. (2014). The Validity and Reliability of the Student Evaluation of Teaching. International Journal for Innovation Education and Research, 2(9), 57-63.

Kogan, L. R., Schoenfeld-Tacher, R., \& Hellyer, P. W. (2010). Student evaluations of teaching: perceptions of faculty based on gender, position, and rank. Teaching in Higher Education, 15(6), 623-636.

Kuzmanovic, M., Savic, G., Gusavac, B. A., Makajic-Nikolic, D., \& Panic, B. (2013).A Conjoint-based approach to student evaluations of teaching performance. Expert Systems with Applications, 40(10), 4083-4089. 
https://doi.org/10.1016/j.eswa.2013.01.039

Kwan, K. P. (1999). How fair are student ratings in assessing the teaching performance of university teachers? Assessment \& Evaluation in Higher Education, 24(2), 181-195. https://doi.org/10.1080/0260293990240207

Lamanauskas, V., \& Makarskaitè-Petkevičienè, R. (2016). University study quality: understanding, improvement, influential factors. Quality Issues and Insights in the 21st Century, 31-45.

Levine, A. (2018). Privatization in higher education. In Privatizing education (pp. 133-148). Routledge.

Lawall, M. (1998). Students rating teaching: How student feedback can inform your teaching. University Teaching Services, Centre for Higher Education Research and Development, University of Manitoba.

MacSuga-Gage, A. S., Simonsen, B., \& Briere, D. E. (2012). Effective Teaching Practices: Effective Teaching Practices that Promote a Positive Classroom Environment. Beyond Behavior, 22(1), 14-22. https://doi.org/10.1177/107429561202200104

Maringe, F., \& Sing, N. (2014). Teaching large classes in an increasingly internationalising higher education environment: pedagogical, quality and equity issues. Higher Education,67(6), 761-782. https://doi.org/10.1007/s10734-013-9710-0

Marsh, H. W. (2007). Students' evaluations of university teaching: Dimensionality, reliability, validity, potential biases and usefulness. In The scholarship of teaching and learning in higher education: An evidence-based perspective (pp. 319-383). Springer, Dordrecht. https://doi.org/10.1007/1-4020-5742-3_9

Mortelmans, D., \& Spooren, P. (2009).A revalidation of the SET37 questionnaire for student evaluations of teaching. Educational Studies, 35(5), 547-552. https://doi.org/10.1080/03055690902880299

Nilson, L. B. (2016). Teaching at its best: A research-based resource for college instructors. John Wiley \&Sons.

Noaman, A. Y., Ragab, A. H. M., Madbouly, A. I., Khedra, A. M., \& Fayoumi, A. G. (2017). Higher education quality assessment model: towards achieving educational quality standard. Studies in Higher Education, 42(1), 23-46. https://doi.org/10.1080/03075079.2015.1034262

Onwuegbuzie, A. J., Daniel, L. G., \& Collins, K. M. (2009). A meta-validation model for assessing the score-validity of student teaching evaluations. Quality \& Quantity, 43(2), 197-209. https://doi.org/10.1007/s11135-007-9112-4

Paolini, A. (2015). Enhancing Teaching Effectiveness and Student Learning Outcomes. Journal of Effective Teaching, 15(1), 20-33.

Price, L., \& Kirkwood, A. (2014).Using technology for teaching and learning in higher education: A critical review of the role of evidence in informing practice. Higher Education Research \&Development, 33(3), 549-564. https://doi.org/10.1080/07294360.2013.841643

Rama, S. (2011). Professor's performance for effective teaching (Kosovo case). Procedia-Social and Behavioral Sciences, 12, 117-121. https://doi.org/10.1016/j.sbspro.2011.02.015

Ramachandran, V. (2010). Gender issues in higher education. United nations educational, scientific and cultural organization (UNESCO). Asia-pacific programme of education for all.

Richardson, J. T. (2005). Students' approaches to learning and teachers' approaches to teaching in higher education. Educational Psychology, 25(6), 673-680. https://doi.org/10.1080/01443410500344720

Sabol, F. R. (2013). Seismic shifts in the education landscape: What do they mean for arts education and arts education policy?. Arts Education Policy Review, 114(1), 33-45. https://doi.org/10.1080/10632913.2013.744250

Sarkis, J., \& Seol, I. (2010). Course evaluation validation using data envelopment analysis. The Accounting Educators' Journal, 20(1).

Sen, S., Das, M., \& Chatterjee, R. (2018). Estimation of Incomplete Data in Mixed Dataset. In Progress in Intelligent Computing Techniques: Theory, Practice, and Applications(pp. 483-492). Springer, Singapore.

Shernoff, D. J., Csikszentmihalyi, M., Schneider, B., \& Shernoff, E. S. (2014). Student engagement in high school classrooms from the perspective of flow theory.In Applications of Flow in Human Development and Education (pp. 475-494).Springer Netherlands. https://doi.org/10.1007/978-94-017-9094-9_24

Slate, J. R., LaPrairie, K. N., Schulte, D. P., \& Onwuegbuzie, A. J. (2011). Views of effective college faculty: A mixed analysis. Assessment \& Evaluation in Higher Education, 36(3), 331-346. 
https://doi.org/10.1080/02602930903428684

Solis, O. J., \& Turner, W. D. (2017). Building positive student-instructor interactions: Engaging students through caring leadership in the classroom. Journal on Empowering Teaching Excellence, 1(1), 4.DOI: 10.15142/T37P72

Spooren, P., Brockx, B., \& Mortelmans, D. (2013). On the validity of student evaluation of teaching: The state of the art. Review of Educational Research, 83(4), 598-642. https://doi.org/10.3102/0034654313496870

Toland, M. D., \& De Ayala, R. J. (2005). A multilevel factor analysis of students' evaluations of teaching. Educational and Psychological Measurement, 65(2), 272-296. https://doi.org/10.1177/0013164404268667

Turhan, K., Yaris, F., \& Nural, E. (2005). Does instructor evaluation by students using a web-based questionnaire impact instructor performance? Advances in Health Sciences Education, 10(1), 5-13. https://doi.org/10.1007/s10459-004-0943-7

Webber, K. L., Krylow, R. B., \& Zhang, Q. (2013). Does involvement really matter? In-dicators of college student success and satisfaction. Journal of College Student Development, 54, 600-609. https://doi.org/10.1353/csd.2013.0090

Weimer, M. (2010).Building rapport with your students. The Teaching Professor, 23(6), 2.

Williams, K. H., Childers, C., \& Kemp, E. (2013). Stimulating and enhancing student learning through positive emotions. Journal of Teaching in Travel \& Tourism, 13, 209-227. https://doi.org/10.1080/15313220.2013.813320

Zuekle, E. (2008). College enrolment rate increases, but financial challenges bring uncertainty. Washington DC: Population Reference Bureau. 